\title{
DAMPAK ZONASI DAN PARIWISATA ATRAKSI HIU PAUS TERHADAP KOMUNITAS KWATISORE
}

\section{The Impact of Zoning and Whale Shark Attraction Tourism Toward Kwatisore Community}

\author{
Rehastidya Rahayu*), Soeryo Adiwibowo dan Arif Satria \\ Program Studi Sosiologi Pedesaan, Fakultas Ekologi Manusia, Sekolah Pascasarjana IPB \\ ${ }^{*}$ E-mail: rehastidyarahayu@yahoo.co.id
}

\begin{abstract}
The establishment of a conservation area, especially the area became a national park is not without a problem. Many research has been done in the area of conservation with the result of people who have long lived in the conservation area be marginalized mainly due to the zoning applied to conservation and tourism. Therefore, this study is intended to explore the impact of zoning and tourism to the marginalization of people living in the national park. This research was conducted in Cenderawasih Bay National Park, especially located in the Kwatisore Village, Nabire District of Papua Province. The method used is qualitative method with data collection technique through in-depth interviews. The research finds, first, zoning do not disturb Kwatisore community access toward resources. Second, tourism gained additional income for the local community by selling souvenir, renting boat, and ritual ceremony for tourist attraction. Third, floating capture fisheries and floating net cage changes fisheries technology and gain additional income. So it can be concluded that zoning, and tourism are not marginalized the Kwatisore community.
\end{abstract}

Keywords: conservation, zoning, tourism, marginalization, community Kwatisore

\begin{abstract}
ABSTRAK
Pembentukan kawasan konservasi, khususnya kawasan yang ditetapkan menjadi taman nasional bukanlah tanpa masalah. Banyak penelitian yang telah dilakukan menunjukkan bahwa pembentukan suatu kawasan menjadi taman nasional berdampak pada terjadinya marginalisasi terhadap masyarakat terutama masyarakat yang telah lama bermukim di kawasan konservasi karena penetapan zonasi dan pariwisata. Oleh karena itu penelitian ini bertujuan untuk menganalisis lebih jauh dampak dari zonasi dan pariwisata terhadap marginalisasi masyarakat yang telah bermukim lama di dalam taman nasional. Penelitian ini dilakukan di Taman Nasional Teluk Cenderawasih khususnya di Kampung Kwatisore, Kabupaten Nabire, Provinsi Papua. Metode penelitian yang digunakan adalah metode kualitatif melalui wawancara mendalam. Hasil penelitian menunjukkan bahwa, pertama, implementasi zonasi di kawasan Perairan Kwatisore tidak mempengaruhi akses komunitas Kwatisore terhadap sumber daya alam. Kedua, adanya pariwisata memberikan penghasilan tambahan terhadap komunitas Kwatisore. Tambahan penghasilan berasal dari penjualan souvenir, penyewaan perahu, dan pengadaan upacara adat penyambutan tamu. Ketiga, dilapangan juga ditemukan bahwa keberadaan bagan dan Keramba Jaring Apung (KJA) memberikan perubahan terhadap teknologi penangkapan sekaligus juga memberikan tambahan pendapatan bagi komunitas Kwatisore. Jadi implementasi zonasi, keberadaan pariwisata, bagan dan KJA tidak menyebabkan terjadinya marginalisasi terhadap komunitas Kwatisore.
\end{abstract}

Kata kunci: konservasi, zonasi, pariwisata, marginalisasi, komunitas Kwatisore

\section{PENDAHULUAN}

Indonesia merupakan negara kepulauan yang memiliki keanekaragaman hayati tertinggi di dunia (megadiversity country). Namun kayanya potensi keanekaragaman hayati selalu diikuti dengan ancaman kepunahan yang berdampak pada kehidupan masyarakat. Oleh karena itulah konservasi dianggap perlu sebagai upaya untuk mempertahankan atau melestarikan keanekaragaman hayati dan ekosistemnya sehingga bisa secara terus-menerus dapat memberikan manfaat dalam mendukung kehidupan manusia. Salah satu kawasan konservasi di Indonesia adalah taman nasional. Namun terbentuknya taman nasional sebagai kawasan konservasi bukanlah tanpa masalah. Permasalahan yang paling utama dalam kawasan konservasi terutama konservasi perairan adalah (1) zonasi, (2) perikanan tangkap dan (3) pariwisata yang semakin berkembang.

Beberapa konflik telah terjadi di kawasan taman nasional salah satunya adalah peristiwa berdarah penembakan nelayan di Taman Nasional Pulau Komodo karena memasuki area konservasi laut. Tahun 1998 ada lima orang nelayan yang ditembak sedangkan tahun 2002 ada dua orang nelayan yang ditembak dan ditahun 2003 sembilan orang nelayan ditangkap karena memasuki kawasan zonasi terlarang (Nahdian \& Fadli 2014). Selanjutnya tahun 2014 tepatnya pada bulan oktober tiga orang nelayan ditangkap karena dituduh memasuki dan merusak kawasan konservasi di Taman Nasional Ujung Kulon (TNUK), padahal ketiganya hanya menggunakan alat penangkapan tradisional berupa jaring dan panah bawah air yang terbuat dari kayu. Disisi usaha penangkapan ikan nelayan tradisional kalah saing dengan nelayan pendatang yang mengambil manfaat dari kawasan taman nasional menggunakan teknologi penangkapan ikan yang lebih canggih. Salah satu contoh kasus yaitu konflik yang terjadi di Taman Nasional Karimunjawa antara nelayan Karimunjawa (lokal) dan nelayan pendatang (Jepara) yang melakukan penangkapan ikan dengan menggunakan alat penangkapan ikan yang lebih modern.

Tumbolon dan Satria (2013) menjelaskan bahwa konflik antara nelayan Karimunjawa dan nelayan Jepara disebabkan oleh perebutan daerah tangkapan dan teknologi penangkapan ikan yang digunakan. Nelayan Karimunjawa dalam 
penangkapan ikan masih menggunakan pancing, bubu, branjang dan jaring. Berbeda dengan nelayan Jepara yang menggunakan mini pursue seine, dan pukat harimau. Selain permasalahan zonasi dan perikanan tangkap, hari ini banyak taman nasional dengan potensi keanekaragaman hayatinya yang tinggi menjelma menjadi kawasan pariwisata. Hasil penelitian yang telah dilakukan oleh Mahmud (2014) di Taman Nasional Bali Barat (TNBB) menunjukkan bahwa kehadiran pariwisata merangsang kedatangan para pengusaha pariwisata yang berdampak pada munculnya kecemburuan sosial terkait semakin sempitnya akses nelayan diperairan laut. Pariwisata yang pada awalnya diharapkan menjadi sarana peningkatan perekonomian masyarakat untuk meningkatkan standar hidupnya tetapi malah berdampak pada semakin terbatasnya ruang gerak masyarakat untuk dapat mengakses sumber daya alam taman nasional. Fenomena yang terjadi di beberapa taman nasional tersebut menunjukkan bahwa terjadi marginalisasi masyarakat dari sumber penghidupannya yaitu sumber daya alam taman nasional. Marginalisasi terjadi ketika akses masyarakat dibatasi terhadap pemanfaatan sumber daya alam yang menjadi tumpuan hidup mereka sedangkan pihak lain yang memiliki kepentingan dalam sumber daya alam memiliki keleluasaan dalam mengambil manfaat karena telah mengantongi izin dari pihak yang memiliki otoritas dalam pengelolaan taman nasional yaitu negara.

Taman Nasional Teluk Cenderawasih (selanjutnya TNTC) merupakan taman nasional terluas di Indonesia yaitu 1.453.500 hektar dengan luas wilayah perairan 1.385.300 hektar lebih luas dibandingkan wilayah daratannya 68.000 hektar. Kawasan TNTC secara administratif terletak di dua provinsi yaitu Kabupaten Manokwari Provinsi Papua Barat, Kabupaten Teluk Wondama Provinsi Papua Barat, Kabupaten Yapen Provinsi Papua, Kabupaten Waropen Provinsi Papua dan Kabupaten Nabire Provinsi Papua (BBTNTC 2012) yang terdiri dari enam puluh empat desa dengan total jumlah penduduk dalam kawasan kurang lebih 3260 orang. TNTC memiliki keanekaragaman hayati yang tinggi termasuk ikan hiu paus yang menjadi icon pariwisata. Penelitian Winara dan Mukhtar (2011) menghasilkan bahwa di kawasan TNTC terjadi benturan kepentingan antara kepentingan perlindungan ekosistem dan pemanfaatan ekonomi. Dalam pemanfaatan ekonomi pemerintah daerah berkolaborasi dengan pihak swasta dalam mendorong investasi terhadap pariwisata dan perikanan tangkap sedangkan disisi lain TNTC merupakan wilayah konservasi yang ditujukan untuk perlindungan sumber daya alamnya. Luasnya wilayah perairan TNTC menjadi daya tarik bagi para nelayan dari luar kawasan seperti nelayan Bugis, nelayan Buton dan nelayan Makassar (yang populer dengan sebutan nelayan BBM) sebagai nelayan bagan yang juga berpartisipasi dalam pengelolaan wisata bahari. Fenomena yang terjadi di Teluk Cenderawasih sedikit banyak memiliki persamaan dengan beberapa kasus yang telah digambarkan sebelumnya. Oleh karena itu pertanyaan dalam penelitian adalah:

1. Apakah dengan hadirnya sistem zonasi komunitas Kwatisore menjadi termarginalkan seperti halnya yang terjadi dikawasan taman nasional lainnya?

2. Apakah kehadiran perusahaan pariwisata dan nelayan bagan di Perairan Kwatisore mengakibatkan struktur akses komunitas Kwatisore mengalami perubahan dan bersama dengan sistem zonasi mengakibatkan marginalisasi?

\section{PENDEKATAN TEORI}

\section{Teori Property Right}

Property right (hak kepemilikan) disadari merupakan faktor penting dalam pengelolaan sumber daya alam (Bromley 1998, 2000; McCay \& Acheson 1990 dalam Lynch \& Harwell 2002). Property right merupakan kewenangan hukum untuk melakukan tindakan tertentu yang berhubungan dengan daerah kekuasaan tertentu (Common 1968 dalam Ostrom \& Schlager 1996) dan juga memainkan aturan pokok dalam pengelolaan sumber daya alam, menyampaikan wewenang, serta membentuk insentif bagi pengelolaan (Meinzen-Dick \& Knox 2001). Dengan demikian property right melibatkan pemilik hak, individu lain dan kelembagaan untuk menyokong klaim mereka dalam menetapkan suatu tindakan dimana individu dapat berhubungan dengan individu lain mengenai "sesuatu" (sumber daya alam).

Ostrom dan Schlager (1996) mengidentifikasi lima property right yang paling relevan digunakan untuk common pool resources yaitu hak akses, hak pemanfaatan, hak pengelolaan, hak eksklusi dan hak pengalihan:

1. Hak Akses (Access Right): hak untuk masuk ke wilayah sumber daya yang memiliki batas-batas yang jelas dan untuk menikmati manfaat non-ekstraktif (contohnya: berjalan-jalan, menaiki kano, atau duduk dibawah sinar matahari)

2. Hak Pemanfaatan (Withdrawal Right): hak untuk memanfaatkan sumber daya atau hak untuk berproduksi (contohnya : menangkap ikan atau mengambil air)

3. Hak Pengelolaan (Management Right): hak untuk menentukan aturan operasional pemanfaatan sumber daya

4. Hak Eksklusi (Exclusion Right): hak untuk menentukan siapa yang boleh memiliki hak akses dan bagaimana hak akses tersebut dialihkan kepada pihak lain

5. Hak Pengalihan (Alienation Right): hak untuk menjual atau menyewakan sebagian atau seluruh hak-hak kolektif tersebut diatas.

Banyaknya hak yang dikuasai oleh seorang aktor, kelompok atau institusi mencerminkan status atau kedudukannya terhadap penguasaan sumber daya alam. Ostrom dan Schlager (1996) menjelaskan status tersebut terdiri dari status sebagai authorized entrant, authorized user, claimant, proprietor, dan owner. Authorized entrant merupakan status dimana individu hanya mendapatkan hak untuk mengakses sumber daya. Misalkan pengunjung taman nasional yang memiliki hak untuk memasuki dan menikmati taman tapi tidak untuk mendapatkan kayu atau produk hutan lainnya. Authorized user ditetapkan oleh orang lain yang memegang hak pilih kolektif untuk mengelola dan mengekslusi, namun tidak memiliki kewenangan untuk merencanakan aturan-aturan memanen sumber daya termasuk melarang pihak lain untuk mendapatkan keuntungan mengakses daerah tangkapan ikan.

Pihak yang memiliki hak akses, hak pemanfaatan, hingga hak pengelolaan disebut sebagai claimant. Melalui hak pengelolaan, claimant miliki kewenangan pilihan kolektif untuk merencanakan hak operasional pemanfaatan. Tetapi claimant tidak dapat secara spesifik menentukan siapa yang boleh dan tidak boleh mengakses sumber daya atau melakukan pengalihan hak pengelolaan sumber daya. Pihak yang memiliki ketiga hak yaitu hak akses, hak pemanfaatan dan pengelolaan serta hak ekslusi disebut sebagai proprietor. Proprietor memiliki kekuasaan menentukan siapa yang boleh mengakses sumber daya dan bagaimana memanfaatkan sumber daya, tetapi tidak memiliki hak untuk melakukan pengalihan hak pilih kolektif. Dan apabila individu atau lembaga memiliki ke lima hak tersebut beserta dengan hak pengalihan dimana 
memiliki kemampuan untuk menjual dan menyewakan sumber daya disebut sebagai owner. Oleh karena itu konsep property right bukanlah konsep sederhana yang hanya mengacu pada kepemilikan yang ditetapkan oleh negara, tetapi konsep yang terdiri dari berbagai tipe bundle of right (ikatan hak) yang berasal dari negara, adat, hukum agama dan kerangka normatif lainnya (Meinzen-Dick \& Knox 2001).

\section{Teori Akses}

Peluso dan Ribot (2003) dalam tulisannya yang berjudul $A$ Theory of Access menjelaskan secara terperinci bahwa akses didefinisikan sebagai kemampuan (ability) untuk mendapatkan keuntungan (benefit) dari "sesuatu", termasuk objek materi, orang, lembaga, dan simbol, yang menekankan pada ikatan kekuasaan (bundle of power). Sedangkan property merupakan hak (right) untuk mendapatkan keuntungan dari sesuatu, yang menekankan pada ikatan hak (bundle of right). Singkatnya, akses memfokuskan pada "kemampuan" sedangkan property berfokus pada "hak". Jadi formulasi tentang akses mencakup sebuah relasi sosial yang mempengaruhi atau memungkinkan seseorang atau kelompok memperoleh keuntungan dari pemanfaatan sumber daya dan tidak terbatas hanya pada hubungan property.

Konsep akses sebenarnya berusaha untuk menjelaskan siapa yang memperoleh keuntungan dari sesuatu dan bagaimana proses yang terjadi ketika individu atau institusi mendapatkan keuntungan tersebut. Gagasan akses memungkinkan aktor untuk memperoleh (gain access), mengontrol (access control) dan memelihara akses (access maintenance) dalam pemanfaatan sumber daya alam.

\section{Marginalisasi}

Marginalisasi merupakan teori yang berasal dari berbagai disiplin ilmu. Dalam tulisan ini marginalisasi didefinisikan sebagai suatu proses yang mengarah pada meminggirkan suatu komunitas atau individu tertentu dari ruang sosial yang pada akhirnya membatasi pilihan hidup mereka baik di bidang politik, sosial, dan ekonomi (Jahan 2016). Singkat kata dan mengacu pada teori akses peluso bahwa marginalisasi mengacu pada pembatasan akses masyarakat terhadap sumber daya.

Marginalisasi yang terjadi di dalam kehidupan masyarakat terutama apabila berhubungan dengan sumber daya alam bukanlah posisi yang dipilih oleh masyarakat. Tetapi ketidakmampuan masyarakat dimana dalam teori Marx mengatakan terdapat beberapa orang yang "memiliki" kekuasaan sedangkan yang lain "tidak memiliki" kekuasaan, mau tidak mau menempatkan mereka di posisi tidak berdaya dan dikendalikan oleh pihak lain yang berkuasa. Posisi tidak berdaya inilah yang membatasi masyarakat dalam upaya mengakses sumber daya.

\section{METODE PENELITIAN}

Penelitian dilaksanakan di Taman Nasional Teluk Cendrawasih, Dusun Kwatisore, Kampung Akudiomi, Kabupaten Nabire, Provinsi Papua pada bulan April 2014. Penelitian ini menggunakan paradigma konstruktivisme. Menurut Denzin dan Lincoln (2009) dalam bukunya The Handbook of Qualitative Research memaparkan bahwa tujuan dari penelitian paradigma konstruktivisme yaitu untuk memahami dan merekonstruksi berbagai konstruksi yang sebelumnya dipegang oleh penelitim namun terbuka apabila adanya interpretasi baru seiring dengan perkembangan informasi dan kecanggihan teknologi. Posisi peneliti dalam paradigma ini sebagai partisipan dan fasilitator. Konstruksi peneliti muncul dari aktivitas penelitian yang dinilai dari data dan informasi yang dimiliki; sejauh mana "kegunaan" konstruksi tersebut, dalam arti memberikan tingkat penjelasan yang meyakinkan; dan sejauh mana memiliki "relevansi" dan "dapat dimodifikasi". Dalam konstruktivis suatu "realitas sosial" dibentuk berdasarkan interaksi antara peneliti dengan individu atau kelompok yang diteliti.

Metode penelitian yang digunakan adalah metode kualitatif dengan pendekatan studi kasus guna memudahkan mendapatkan data dalam waktu yang singkat. Data yang digunakan dalam penelitian adalah data primer dan data sekunder. Data primer dikumpulkan melalui observasi dan wawancara mendalam dengan informan. Data sekunder dikumpulkan melalui dokumen-dokumen yang terkait dengan penelitian. Pemilihan informan yang diwawancarai dilakukan secara purposive. Informan yang dipilih merupakan informan yang paling mengetahui dan menguasai permasalahan yang dibahas di dalam penelitian. Total jumlah informan dalam penelitian ini adalah 32 orang yang terdiri dari Kepala Distrik Yaur, Kepala Kampung Akudiomi, tokoh adat, tokoh dari marga, Komunitas Kwatisore, Kepala BBTNTC beserta staff, nelayan dan pemilik bagan, penjaga keramba jaring apung, LSM WWF, Kali Lemon Dive Resort (KLDR), akademisi UNIPA, operator wisata liveaboard, dan Dinas Kelautan dan Perikanan (DKP) Kabupaten Nabire. Data-data yang diperoleh dari hasil wawancara dikumpulkan dengan pencatatan yang dilakukan setiap harinya disebut catatan harian. Hasil catatan harian tersebut kemudian di reduksi untuk mencari informasiinformasi yang sesuai dengan kebutuhan penelitian.

\section{HASIL DAN PEMBAHASAN}

\section{Keanekaragaman Hayati Taman Nasional Teluk Cendrawasih (TNTC)}

Keanekaragaman hayati TNTC memiliki lima tipe ekosistem yaitu ekosistem hutan tropis daratan/pulau, ekosistem hutan pantai, ekosistem hutan mangrove, ekosistem padang lamun dan ekosistem terumbu karang. Keanekaragaman ekosistem inilah yang menjadikan TNTC sebagai taman nasional yang memiliki keanekaragaman flora dan fauna yang tinggi. Salah satu fauna yang sangat penting sekaligus menjadi icon daya tarik wisata di TNTC adalah hiu paus (whale shark). Hiu paus (Rhincodon typus) merupakan spesies ikan jenis hiu terbesar di dunia dengan panjang dapat mencapai hingga 18-20 meter. Makanan utama hiu paus adalah beranekaragam jenis plankton, cumi-cumi, dan ikan-ikan kecil. Hiu paus di TNTC sedikit berbeda dibandingkan dengan hiu paus dari negara lain berdasarkan kemunculannya di kawasan. Di Filiphina dan Australia keberadaan hiu paus muncul secara musiman. Di Australia kemunculan hiu paus biasanya terjadi setiap musim gugur di bulan April hingga awal bulan Mei. Namun, hiu paus di TNTC dapat dijumpai sepanjang tahun. Di TNTC, hiu paus dapat dengan mudah dijumpai di kawasan Perairan Kampung Kwatisore. Kemunculan hiu paus di wilayah Perairan Kwatisore menjadikan kampung tersebut sebagai tujuan wisata utama yang terkenal baik domestik maupun mancanegara.

\section{Proses Terbentuknya Zonasi}

TNTC secara resmi ditetapkan sebagai taman nasional pada tahun 2002 berdasarkan Surat Keputusan Menteri Kehutanan 
Nomor 8009/Kpts-II/2002 pada tanggal 29 Agustus 2002. TNTC dikelola dengan sistem zonasi dibawah pengawasan Balai Besar Taman Nasional Teluk Cenderawasih (BBTNTC). Fatem et al (2011) mengemukakan bahwa proses perencanaan zonasi TNTC dilakukan melalui berbagai tahapan yaitu:

1. Rencana Pengelolaan konservasi laut Teluk Cenderawasih Irian Jaya Tahun 1988-1992;

2. Rencana Pengelolaan Taman Nasional Teluk Cenderawasih Tahun 1994-2019 Lima Tahun Rencana Pengelolaan Taman Naional Teluk Cenderawasih Tahun 1994-2019;

3. Rencana pengelolaan dan zonasi Taman Nasional Teluk Cenderawasih kerjasama pemerintah Kabupaten Manokwari dan Kabupaten Nabire, WWF dan BBTNTC tanggal 29-31 Oktober 2001;

4. Mulai tahun 2000-2009 terdapat berbagai seminar, workshop dan konsultasi publik dalam upaya pengonsepan pembentukan zonasi TNTC.

Seminar, workshop, dan konsultasi publik melibatkan banyak kalangan diantaranya adalah masyarakat lokal, tokoh agama, tokoh masyarakat, pihak akademisi, pemerintah daerah Kabupaten Teluk Wondama dan Kabupaten Nabire. Oleh karena itu sistem zonasi yang digunakan pada kawasan TNTC meminjam istilah Fatem et al (2011) disebut sebagai "community-based zoning" atau disebut juga zonasi dari komunitas.

Proses pembentukan zonasi TNTC tidak berlangsung singkat, proses ini berlangung selama enam tahun yaitu dari tahun 2002 - 2008 dan menunjukkan hasil pada tahun 2009 . Lamanya proses zonasi, disebabkan oleh lamanya waktu yang diperlukan untuk mengadakan konsultasi publik dengan berdiskusi bersama komunitas dari tingkat desa hingga tingkat provinsi. Hasilnya, zonasi TNTC dibagi menjadi enam zona yaitu (1) zona inti; (2) zona perlindungan bahari/rimba; (3) zona pemanfaatan pariwisata; (4) zona pemanfaatan umum; (5) zona tradisional; (6) zona khusus. Zona tradisional dikhususkan untuk digunakan oleh masyarakat yang bermukim didalam kawasan konservasi, sedangkan zona pemanfaatan umum dapat digunakan oleh pengguna dari luar kawasan. Setelah penetapan Teluk Cenderawasih sebagai taman nasional dan sistem zonasi telah ditentukan, langkah selanjutnya yang dilakukan BBTNTC bekerja sama dengan pemerintah daerah, LSM dan pihak akademisi melakukan sosialisasi kepada masyarakat dan pengguna TNTC.

\section{Komunitas Kwatisore}

Kampung Kwatisore merupakan salah satu kampung yang terletak di dalam kawasan TNTC dengan luas $246 \mathrm{~km}^{2}$. Penduduk Kampung Kwatisore (Akudiomi) berasal dari Suku Yaur dan dalam berkomunikasi sehari-hari menggunakan Bahasa Yaur. Penduduk Kampung Kwatisore terdiri dari sembilan marga yaitu (1) Marga Inggeruhi, (2) Marga Aduari, (3) Marga Numobogre, (4) Marga Andoi, (5) Marga Hamberi, (6) Marga Yamban, (7) Marga Musyeri, (8) Marga Abowi dan (9) Marga Nahumoni. Marga tertua di Kampung Kwatisore adalah Marga Inggeruhi.

Penduduk Kampung Kwatisore sama halnya dengan penduduk di kampung lainnya yang berdomisili di dalam kawasan TNTC dikategorikan sebagai masyarakat peramu. Hal ini disebabkan karena sebagian besar aktivitas kehidupannya masih memanfaatkan sumber daya alam disekitarnya baik di darat maupun di laut. Namun berdasarkan lamanya curahan waktu, penduduk Kwatisore lebih banyak menghabiskan aktivitasnya di laut dibandingkan di darat. Oleh karena itu menjadi nelayan merupakan mata pencaharian dominan penduduk Kwatisore. Sedangkan selain melaut penduduk Kwatisore juga berkebun, berternak, berburu, dan meramu sagu.

Penduduk Kampung Kwatisore mayoritas beragama Kristen Protestan. Sebagai masyarakat yang religious agama merupakan salah satu faktor yang mengatur kehidupan sehari-hari warga. Dahulu sebelum agama Kristen Protestan masuk ke Kampung Kwatisore, penduduk pergi melaut setiap hari. Ketika agama Kristen Protestan masuk ke kampung, penduduk Kwatisore memiliki waktu-waktu tertentu untuk pergi melaut. Mulai hari senin hingga hari jumat merupakan waktu penduduk Kwatisore mencari nafkah sedangkan hari sabtu dan hari minggu semua aktivitas dihentikan. Hari sabtu dijadikan hari libur karena masyarakat melakukan persiapan untuk acara gereja dihari minggu. Dan hari minggu adalah waktu beribadah.

Struktur masyarakat adat TNTC umumnya dikepalai oleh seorang kepala suku yang berasal dari marga tertua yang pertama kali menempati atau membentuk suatu kampung. Sebagai masyarakat yang berasal dari Suku Yaur, Kampung Kwatisore bersama Kampung Yaur, Kampung Napan Yaur dan Kampung Bowei yang juga terletak di pesisir TNTC dipimpin oleh seorang kepala Suku Yaur. Kepala Suku Yaur berperan dalam pengambilan keputusan mengenai permasalahan marga atau pun permasalahan hak ulayat kampung. Di bawah kepala suku terdapat kepala adat yang mewakili kepala suku di kampung dan berperan dalam mengorganisir acara-acara adat sekaligus menegakkan aturan adat di kampung. Selain itu kepala adat juga bekerjasama dengan kepala kampung. Kepala Kampung berperan dalam mengatur segala bentuk pemerintahan formal kampung terutama dalam mengorganisir pemilihan umum atau pemberian bantuan-bantuan dari pemerintah pusat maupun daerah kepada kampung. Setelah kepala adat terdapat tua marga. Tua marga merupakan orang yang paling tua dalam suatu marga tertentu yang memiliki kuasa atas marga tersebut sekaligus juru bicara marga.

Di Kampung Kwatisore pendapat mengenai kepala Suku Yaur mengalami pro dan kontra terutama dari para tua marga. Sebagian besar tua marga tidak mengakui adanya kepala suku. Hal ini disebabkan oleh tiga faktor yaitu (1) kepala suku lebih memilih bertempat tinggal di Kabupaten Nabire; (2) dipilih oleh pemerintah dan (3) menunjuk diri sendiri. Oleh karena itu semua keputusan yang dikeluarkan oleh kepala suku terutama yang berkaitan dengan pemanfaatan dan pengelolaan hak ulayat tidak diterima dengan baik oleh masyarakat kampung. Selain itu kepala adat di Kampung Kwatisore juga tidak berperan aktif. Alhasil semua keputusan baik yang menyangkut pemerintahan maupun adat dilakukan sepenuhnya oleh kepala kampung.

\section{Aktor dan Akses}

Setiap aktor dalam pengelolaan dan pemanfaatan sumber daya di TNTC apapun kepentingannya tidak bekerja secara sendiri. Mereka membangun relasi antar aktor guna mencapai tujuan mereka dalam pemanfaatan sumber daya. Kegiatan dan tujuan para aktor dapat dilihat melalui tabel 1. Dalam usahanya untuk memanfaatkan sumber daya setiap aktor harus memiliki perizinan untuk mengakses sumber daya baik izin secara formal maupun informal.

Secara formal memperoleh izin akses untuk memanfaatkan sumber daya TNTC diperoleh dari dua instansi pemerintah 
yaitu BBTNTC dan DKP. Perizinan yang diberikan BBTNTC selaku pengelola TNTC terkait dengan akses masuk ke dalam kawasan yang dilegalisasi oleh Surat Izin Masuk Kawasan Konservasi (SIMAKSI). Setiap pihak yang memasuki TNTC harus memiliki SIMAKSI, apabila tidak memiliki maka akan diberikan sangsi karena memasuki kawasan secara illegal. SIMAKSI umumnya dominan diberikan kepada para wisatawan dan peneliti.

Perizinan yang diberikan DKP terkait dengan akses pemanfaatan sumber daya perikanan. Perizinan akses untuk pemanfaatan sumber daya perikanan diberikan kepada aktor secara bersyarat, yaitu harus memiliki Surat Izin Penangkapan Ikan (SIPI) dan/atau Surat Izin Usaha Perikanan (SIUP). Perizinan dari DKP diberikan kepada nelayan bagan, Keramba Jaring Apung (KJA) dan nelayan lainnya yang berasal dari luar kawasan TNTC. Nelayan dari luar kawasan yang memiliki surat-surat tersebut berarti telah memiliki legalisasi dalam memanfaatkan sumber daya perikanan Perairan Kwatisore. Walaupun dilapangan masih banyak ditemukan nelayan dari luar kawasan yang tidak memiliki surat atau mereka memiliki surat izin tetapi telah kadaluarsa.

Berbeda dengan perizinan formal, memperoleh akses melalui izin informal dari komunitas Kwatisore membutuhkan relasi yang baik antara aktor dan pihak komunitas Kwatisore selaku pemilik hak ulayat di Perairan Kwatisore. Walaupun telah memiliki izin resmi, aktor dari luar kawasan TNTC tetap harus mendapatkan izin dari warga Kwatisore. Apabila tidak memiliki izin dari warga Kwatisore maka aktor tersebut dapat diusir oleh warga Kwatisore.

Nelayan bagan atau yang biasa disebut nelayan BBM memanfaatkan sumber daya perikanan terutama ikan puri/teri (Stolephorus spp). Masuknya bagan ke Perairan Kwatisore dapat dilakukan dengan tiga cara selain mendapatkan perizinan formal dari DKP. Cara pertama, pemilik bagan mendatangi kepala Suku Yaur kemudian kepala suku Yaur akan bermusyawarah bersama dengan kepala adat, kepala kampung, dan tua-tua marga kemudian izin dikeluarkan oleh kepala suku Yaur berdasarkan hasil musyawarah. Cara kedua, pemilik bagan langsung menemui salah seorang warga kampung kemudian warga tersebut menyampaikannya kepada kepala kampung. Kepala kampung selaku pemimpin kampung dapat memberikan perizinan walaupun tanpa musyawarah terlebih dahulu dengan tua-tua marga. Dalam hal ini keputusan kepala kampung dianggap merupakan keputusan warga kampung. Cara ketiga merupakan cara yang paling banyak diterapkan dalam mendapatkan izin akses sumber daya perikanan di Perairan Kwatisore. Pemilik bagan hanya menemui salah seorang warga Kampung Kwatisore kemudian ketika izin diperoleh maka bagan dapat langsung beroperasi di Perairan Kwatisore. Sedangkan kepala kampung memberikan legitimasi setelah bagan masuk dan mulai beroperasi.

Aktor lainnya yang juga memanfaatkan sumber daya perikanan adalah Keramba Jaring Apung (KJA). Sekitar tahun 2010 KJA UD Pulau Mas dibawa masuk oleh DKP ke TNTC. Keberadaan KJA awalnya tidak diterima oleh masyarakat TNTC, namun setelah DKP memberikan pemahaman akhirnya masyarakat menerima keberadaan KJA. KJA dapat diterima oleh masyarakat karena besarnya peran serta nelayan lokal. Ikan yang ditampung oleh KJA yaitu ikan kerapu dan lobster umumnya berasal dari hasil tangkapan nelayan lokal yang menjadi anggota KJA. Tidak hanya nelayan anggota, nelayan dari luar anggota pun juga bisa menjual ikan kerapu atau lobster ke KJA.
Relasi yang baik juga terjalin antara penjaga KJA yang umumnya berasal dari Pulau Jawa seperti Solo dan Yogyakarta dengan warga Kwatisore. Relasi terbentuk dari penjaga KJA yang sering berbelanja ke kampung apabila kebutuhan makanan dan minuman di keramba habis. Penjaga keramba juga sering menumpang perahu warga Kwatisore pulang pergi dari Kwatisore menuju ke Nabire dan sebaliknya untuk berbelanja kebutuhan hidup sehari-hari.

Selain pemanfaatan sumber daya perikanan, pariwisata di Perairan Kwatisore juga berkembang dengan sangat pesat. Kali Lemon Dive Resort (KLDR) merupakan salah satu dan satu-satunya operator wisata yang berlokasi di dalam kawasan TNTC. Perizinan atas aktivitas dan lokasi KLDR masih bersifat informal yaitu langsung dari warga Kwatisore khususnya kepala kampung yang mengelola kawasan Kwatisore. Perizinan diberikan dengan persyaratan setiap ada turis yang datang ke kawasan Kwatisore akan memberikan pembayaran sebesar 300 ribu rupiah per turis atas perizinan yang diberikan sesuai dengan kesepakatan yang telah dimusyawarahkan antara KLDR dan warga Kwatisore. Penetapan besarnya nominal yang harus dibayarkan merupakan hasil musyawarah antara KLDR dan warga Kwatisore. Dan aturan tersebut juga berlaku bagi semua operator wisata yang membawa turis ke Perairan Kwatisore.

Pengoperasian jalannya wisata hiu paus tidak bisa berjalan dengan lancar tanpa kehadiran bagan. Hasil tangkapan bagan yang berupa ikan puri merupakan faktor yang dapat memicu kemunculan hiu paus ke permukaan laut. Oleh karena itu keberadaan bagan sangat didukung oleh KLDR. Setiap ada turis yang datang mengunjungi Kwatisore untuk melihat hiu paus dipastikan tujuan utama para turis adalah bagan terlebih dahulu dibandingkan kedatangan mereka ke kampung. Oleh karena itu terjadi hubungan simbiosis mutualisme yang terbangun antara KLDR dan nelayan bagan.

\section{Dampak Zonasi dan Wisata Atraksi Hiu Paus terhadap Komunitas Kwatisore}

\section{Dampak Zonasi}

Taman Nasional Teluk Cenderawasih (TNTC) merupakan kawasan pelestarian alam yang dikelola dengan sistem zonasi dan digunakan untuk tujuan penelitian, ilmu pengetahuan, pendidikan, budidaya, pariwisata dan rekreasi. TNTC terdiri dari 6 zona dimana zona inti dan zona perlindungan bahari/ rimba tidak diperuntukan untuk kegiatan pengambilan sumber daya. Kawasan yang termasuk ke dalam zona inti meliputi 21 lokasi dengan tiga lokasi terletak di wilayah Kwatisore yaitu Pulau Kumbur, Pulau Nutabari dan Pulau Nuburi. Sedangkan kawasan yang termasuk ke dalam zona perlindungan bahari/ rimba di wilayah Kwatisore yaitu Pulau Nuburi, Pulau Kumbur hingga Nutabari, Pulau Nurage, Pulau Manimaje, Pulau Nusir, Pulau Papaya dan Pulau Tiga. Selain pelarangan pemanfaatan di zona inti dan zona perlindungan bahari/rimba, terdapat juga beberapa spesies yang dilindungi di kawasan Kwatisore seperti kima, penyu, dugon dugong, hiu paus dan jenis ikan hiu lainnya. Namun di kawasan Perairan Kwatisore penetapan zonasi tidak menjadi penghalang komunitas Kwatisore untuk mengakses Sumber daya alamnya. Hal ini disebabkan oleh (1) costumary property right; (2) tradisi acara adat; dan (3) ketidaktahuan masyarakat terhadap batasan zonasi.

Secara sosio-historis, pengelolaan Teluk Cenderawasih sebelum ditetapkan sebagai taman nasional, penguasaan dan kepemilikan sumber daya diatur dan dikelola oleh komunitas 


\begin{tabular}{|c|c|c|}
\hline $\begin{array}{l}\text { Aktor Pengelola } \\
\text { dan Pengguna } \\
\text { Sumber daya }\end{array}$ & Kepentingan \& Kegiatan & Lokasi \\
\hline BBTNTC & $\begin{array}{l}\text { Konservasi keanekaragaman hayati dan perlindungan hutan yang } \\
\text { berfokus pada kelestarian keanekaragaman hayati dan ekosistem } \\
\text { sumber daya hutan dan laut dengan penekanan pengelolaan } \\
\text { kawasan berbasis zonasi. }\end{array}$ & Wilayah Teluk Cenderawasih \\
\hline Wisatawan & $\begin{array}{l}\text { Menikmati panorama alam TNTC dengan mengikuti program } \\
\text { wisata yang ditawarkan oleh perusahaan wisata. }\end{array}$ & $\begin{array}{l}\text { Kawasan Teluk Cenderawasih } \\
\text { khususnya Perairan Kwatisore yang } \\
\text { terkenal dengan pariwisata hiu paus }\end{array}$ \\
\hline $\begin{array}{l}\text { Perusahaan Wisata } \\
\text { (Kali Lemon Dive } \\
\text { Resort) }\end{array}$ & $\begin{array}{l}\text { - Mengusung keindahan wisata bahari yang ditawarkan } \\
\text { kepada wisatawan berupa diving atau snorkling bersama Hiu } \\
\text { Paus, night bagan tour (fishing process) house of reef diving } \\
\text { dan sport fishing (C\&R), paradise bird watching, village } \\
\text { tour dan Papua culture. } \\
\text { Bekerjasama dengan bagan dalam aktivitas pariwisata hiu } \\
\text { paus }\end{array}$ & Perairan Kwatisore \\
\hline Nelayan Bagan & $\begin{array}{l}\text { - } \quad \text { Memanfaatkan sumber daya perikanan } \\
\text { - } \quad \text { Memanfaatkan ikan puri yang merupakan hasil tangkapan } \\
\text { utama untuk pariwisata hiu paus } \\
\text { - } \quad \text { Bekerjasama dengan KLDR }\end{array}$ & Perairan Kwatisore \\
\hline $\begin{array}{l}\text { Keramba Jaring } \\
\text { Apung (KJA) }\end{array}$ & $\begin{array}{l}\text { Menampung ikan hasil tangkapan nelayan baik nelayan anggota } \\
\text { maupun non-anggota. Ikan yang ditampung adalah jenis ikan } \\
\text { karang yaitu ikan kerapu dan lobster yang akan dibawa ke Bali } \\
\text { dan kemudian diekspor ke China, Hongkong dan Taiwan }\end{array}$ & $\begin{array}{l}\text { Windesi, Nusrowi, Yaur, dan } \\
\text { Kwatisore }\end{array}$ \\
\hline $\begin{array}{l}\text { Dinas Kelautan } \\
\text { Perikanan (DKP) } \\
\text { Kabupaten Nabire }\end{array}$ & $\begin{array}{l}\text { Mengelola pemanfaatan sumber daya perikanan dengan } \\
\text { menentukan pelegalan pihak-pihak yang ingin memanfaatkan } \\
\text { sumber daya perikanan. }\end{array}$ & $\begin{array}{l}\text { Teluk Cenderawasih yang masuk } \\
\text { wilayah Kabupaten Nabire }\end{array}$ \\
\hline
\end{tabular}

Sumber: Data diolah

Kwatisore atau disebut juga dengan customary property right. Komunitas Kwatisore telah bermukim sejak puluhan tahun lalu di Teluk Cenderawasih dan memiliki aturan-aturan tersendiri terhadap pengelolaan laut di sekitar kampung. Aturan-aturan tersebut tidak tertulis secara formal tetapi telah

dipahami dan dipraktekkan oleh warga Kwatisore sejak zaman nenek moyang mereka. Oleh karena itu masyarakat secara tunggal memiliki kekuasaan penuh sebagai owner baik secara defacto maupun dejure dalam pengelolaan dan pemanfaatan sumber daya alam Teluk Cenderawasih.

Penguasaan pengelolaan kawasan konservasi mulai menonjol dikuasai oleh rezim negara (state property regime) dimulai pada era pemerintahan orde baru. Teluk Cenderawasih ditetapkan sebagai kawasan konservasi demi perlindungan dan keberlanjutan dari sumber daya alamnya. Negara menurut aturan formal merupakan pengelola tertinggi sumber daya alam di Indonesia dengan status hak penguasaan sebagai owner. Perwakilan negara di TNTC dilakukan oleh BBTNTC sebagai unit pelaksana teknis dalam pengelolaan sumber daya alam TNTC. Artinya BBTNTC memiliki kontrol yang kuat terhadap jalannya pengelolaan TNTC.

Menariknya nelayan lokal selaku warga Kwatisore mempunyai tipe hak penguasaan juga sebagai owner. Perbedaannya, status owner BBTNTC merupakan status property right secara defacto yang disahkan oleh undang-undang sedangkan status property right masyarakat Kwatisore secara dejure berdasarkan adat istiadat dan pengakuan masyarakat pesisir TNTC. Artinya baik BBTNTC maupun masyarakat Kwatisore memiliki hak yang sama dalam menentukan siapa yang boleh dan tidak boleh mengambil manfaat dari sumber daya, juga memiliki kemampuan untuk menjual dan menyewakan sumber daya kepada pihak tertentu.

Dinas Kelautan dan Perikanan (DKP) memiliki status sebagai proprietor yang memiliki wewenang dalam menentukan siapa yang boleh mengakses sumber daya dan bagaimana memanfaatkan sumber daya berlandaskan pada perundangundangan dan keputusan dari Kementerian Kelautan dan Perikanan (KKP). DKP lebih cenderung berhubungan dengan usaha sumber daya perikanan melalui pemberian izin kepada nelayan-nelayan yang berasal dari luar kawasan.

Nelayan bagan dan KJA berstatus sebagai authorized user yang berkemampuan untuk memanen dan menjual sumber daya perikanan yang mereka dapatkan namun tidak memiliki wewenang dalam merencanakan aturan termasuk melarang pihak lain untuk mengakses daerah tangkapan ikan ditempat yang sama. Sedangkan pengusaha pariwisata/tour operator khususya KLDR berstatus sebagai authorized entrant. Pengusaha pariwisata bersama dengan wisatawan hanya mendapatkan hak untuk masuk menikmati sumber daya alam Perairan Kwatisore tanpa mengambil dan membawa sumber daya alam tersebut keluar dari kawasan TNTC. Jadi secara garis besar terjadi perubahan struktur akses masyarakat dalam penguasaan sumber daya alam Teluk Cenderawasih sebelum dan sesudah ditetapkan sebagai taman nasional, dan semakin banyak pihak yang terlibat dalam pengelolaan dan pemanfaatan sumber daya alam.

Namun, walaupun terjadi perubahan struktur akses dalam hak penguasaan sumber daya di TNTC khususnya di Perairan Kwatisore, keberadaan komunitas Kwatisore dalam pengelolaan Perairan Kwatisore masih sangat kuat. Oleh karena itu keberadaan zonasi secara garis besar tidak mengganggu aktivitas warga dalam menangkap ikan. Dari 
Tabel 2. Tipe Hak Penguasaan Sebelum Ditetapkan Sebagai Taman Nasional

\begin{tabular}{|c|c|c|c|}
\hline No & Aktor & $\begin{array}{l}\text { Status Hak } \\
\text { Penguasaan }\end{array}$ & Pemberi Hak \\
\hline 1 & Nelayan Lokal & $\begin{array}{l}\text { Owner (defacto } \\
\text { dan dejure) }\end{array}$ & $\begin{array}{l}\text { Komunitas } \\
\text { Kwatisore }\end{array}$ \\
\hline 2 & Nelayan Bagan & authorized user & $\begin{array}{l}\text { Komunitas } \\
\text { Kwatisore }\end{array}$ \\
\hline
\end{tabular}

Sumber: Data diolah

dahulu hingga sekarang mata pencaharian warga Kwatisore adalah sebagai nelayan dan hal ini masih terus berlanjut hingga saat ini. Memang keberadaan sistem zonasi telah mengatur kawasan dan jenis spesies ikan yang boleh dan tidak boleh ditangkap. Namun aturan zonasi, tidak diindahkan oleh warga Kwatisore. Hal ini disebabkan dari dahulu hingga sekarang hak penguasaan komunitas Kwatisore berstatus tetap sebagai owner sumber daya alam Perairan Kwatisore.

Warga Kwatisore masih mengambil spesies yang dilindungi. Umumnya spesies yang diambil adalah penyu. Penyu banyak digunakan pada pesta adat warga Kwatisore seperti upacara pernikahan. Penyu digunakan untuk memberikan sajian makanan kepada para tamu-tamu yang diundang. Selain penyu ada juga masyarakat yang mengambil kima namun saat ini sudah sangat jarang terjadi. Kima diambil untuk dikonsumsi dagingnya dan kulit kima dibakar untuk dijadikan kapur sirih. Faktor lainnya yaitu ketidaktahuan warga kwatisore terhadap batas zonasi. Pemahaman tentang sistem zonasi hanya diketahui oleh sebagian kecil warga Kwatisore seperti kepala kampung dan tua-tua marga. Sedangkan untuk warga Kwatisore secara keseluruhan masih belum memahami sistem zonasi terutama batasan dan fungsi dari setiap zonasi. Mereka hanya pernah mendengar ada kawasan zonasi. Tetapi tidak memiliki pemahaman tentang aturan yang mengatur dimana kawasan yang boleh dan tidak boleh dilakukan penangkapan. Oleh karena itu masih ada warga Kwatisore yang mengambil ikan di zona inti dan zona perlindungan bahari seperti di Pulau Nuburi dan di zona rimba dan zona pemanfaatan pariwisata seperti di Pulau Papaya. Hal ini dilakukan bukan karena kesengajaan tetapi melainkan karena kebiasaan. Bagi nelayan yang hanya menangkap ikan untuk one day fishing biasanya tidak sampai hingga ke Pulau Nuburi dan Pulau Papaya, tetapi berlaku untuk nelayan yang melaut lebih dari dua hari.

BBTNTC selaku pihak pengelola yang dilegitimasi oleh undang-undang sebenarnya tidak dapat berbuat banyak apabila pelanggaran dilakukan oleh warga Kwatisore sendiri. Umumnya hanya memberikan teguran lisan apabila bertemu ketika sedang melakukan patroli yang tidak sering dilakukan karena keterbatasan dana mengingat luasnya kawasan TNTC. Selain dari warga Kwatisore pelanggaran zonasi juga dilakukan oleh nelayan bagan. Nelayan bagan selaku nelayan yang berasal dari luar kawasan seharusnya beroperasi di zona pemanfaatan umum. Tetapi pada umumnya saat ini nelayan bagan banyak beroperasi di zona tradisional. Padahal zona tradisional diperuntukkan untuk nelayan yang bermukim di dalam kawasan TNTC. BBTNTC juga tidak dapat bertindak tegas kepada nelayan bagan. Hal ini disebabkan oleh kekhawatiran BBTNTC akan semakin berkurangnya wisatawan yang datang apabila bagan dipindahkan dari zona tradisional karena kehadiran bagan memicu naiknya hiu paus ke permukaan air laut yang menjadi wisata utama di Perairan Kwatisore juga TNTC secara umum.
Tabel 3. Tipe Hak Penguasaan TNTC

\begin{tabular}{|c|c|c|c|}
\hline No & Aktor & $\begin{array}{l}\text { Status Hak } \\
\text { Penguasaan }\end{array}$ & Pemberi Hak \\
\hline 1 & BBTNTC & $\begin{array}{l}\text { Owner } \\
\text { (defacto) }\end{array}$ & $\begin{array}{l}\text { Negara } \\
\text { (KLHK) }\end{array}$ \\
\hline 2 & Nelayan Lokal & $\begin{array}{l}\text { Owner } \\
\text { (dejure) }\end{array}$ & $\begin{array}{l}\text { Komunitas } \\
\text { Kwatisore }\end{array}$ \\
\hline 3 & Nelayan Bagan & $\begin{array}{l}\text { authorized } \\
\text { user }\end{array}$ & $\begin{array}{l}\text { Komunitas } \\
\text { Kwatisore dan } \\
\text { DKP }\end{array}$ \\
\hline 4 & $\begin{array}{l}\text { Keramba Jaring } \\
\text { Apung (KJA) }\end{array}$ & $\begin{array}{l}\text { authorized } \\
\text { user }\end{array}$ & $\begin{array}{l}\text { Komunitas } \\
\text { Kwatisore dan } \\
\text { DKP }\end{array}$ \\
\hline 5 & $\begin{array}{l}\text { Pengusaha } \\
\text { Pariwisata/Tour } \\
\text { Operator dan } \\
\text { Wisatawan }\end{array}$ & $\begin{array}{l}\text { authorized } \\
\text { entrant }\end{array}$ & $\begin{array}{l}\text { Komunitas } \\
\text { Kwatisore dan } \\
\text { BBTNTC }\end{array}$ \\
\hline 6 & DKP & proprietor & Pemda \\
\hline
\end{tabular}

Sumber: Data diolah

Namun secara penuh perizinan akses masuknya aktor luar kawasan yang ingin mengambil manfaat dari sumber daya Kwatisore berada dibawah wewenang warga Kwatisore terutama izin dari kepala kampung. BBTNTC biasanya hanya bertindak sebagai penasehat yang memberikan sosialisasi mengenai dampak-dampak yang akan terjadi kepada warga Kwatisore dan lingkungan sekitar mereka.

\section{Dampak Atraksi Hiu Paus}

Perairan Kwatisore merupakan salah satu tempat tujuan mobilisasi hiu paus. Oleh karena itulah atraksi hiu paus menjadi icon pariwisata Kabupaten Nabire. Pariwisata atraksi hiu paus merupakan wisata dimana wisatawan dapat berenang dan menyelam bersama hiu paus dari jarak yang sangat dekat. Tingginya kedatangan wisatawan ke Perairan Kwatisore memberikan dampak positif dan negatif bagi bagi warga Kwatisore. Dampak positifnya yaitu secara ekonomi warga Kwatisore mendapatkan tambahan pendapatan. Dampak negatifnya adalah semakin pudarnya mitos hiu paus dikalangan warga Kwatisore.

Tambahan pendapatan warga Kwatisore umumnya berasal dari permintaan KLDR yaitu dari penyelenggaraan upacara adat penjemputan tamu dan penyewaan perahu. Selain itu warga Kwatisore juga mendapatkan tambahan pendapatan dari souvenir yang dibeli wisatawan dan fee bagi warga yang bekerja untuk KLDR. Pendapatan dari upacara adat yang dikelola oleh kepala kampung, warga Kwatisore mendapat pendapatan sebesar satu juta rupiah, penyewaan perahu sebesar satu juta rupiah dalam satu hari, pembelian souvenir yang memiliki beragam harga sebagai contoh seorang wisatawan pernah membeli dayung warga Kwatisore (wisatawan mau membeli dayung bekas pakai tidak mau membeli dayung yang baru) sebesar dua ratus ribu dan fee sebesar $300-1,5$ juta bagi warga Kwatisore yang bekerja di KLDR. Besarnya fee yang diterima warga bergantung dari banyaknya tamu datang dan terkadang warga juga mendapatkan tip dari wisatawan. Selain dari sektor wisata, warga Kwatisore juga mendapatkan pendapatan tambahan fee yang didapatkan dari nelayan bagan dan KJA yang beroperasi di Perairan Kwatisore.

Negatifnya pariwisata hiu paus semakin lama semakin merubah persepsi masyarakat terhadap hiu paus. Hiu paus dikalangan warga Kwatisore memiliki mitos yang telah 
diceritakan dari generasi ke generasi. Jaja (2014) menjelaskan bahwa mitos merupakan cerita yang dipercaya kebenarannya dan berawal dari sejarah masa lalu dari masa nenek moyang. Mitos dipandang sebagai sesuatu yang diperlukan manusia untuk mencari kejelasan tentang alam lingkungannya, juga sejarah masa lampau (Humaeni 2012). Oleh karena itu mitos bukanlah persoalan benar atau salah, melainkan keberadaan dan kegunaannya bagi masyarakat.

Mitos dikalangan warga Kwatisore adalah anggapan warga bahwa hiu paus merupakan hantu laut. Hal ini disebabkan selain dari ukurannya yang sangat besar, hiu paus juga sering muncul secara tiba-tiba dan "menyerang" warga Kwatisore ketika mereka sedang pergi melaut untuk mencari ikan. Warga Kwatisore khawatir hiu paus merupakan ikan buas yang siap memangsa manusia sehingga dahulu masyarakat merasa takut dengan hiu paus. Selain itu terdapat juga kepercayaan masyarakat akan mitos yang menganggap hiu paus membawa kedukaan bagi keluarga mereka apabila warga bertemu hiu paus ketika melaut.

\section{"dulu kalo kitorang bertemu hiu paus di laut pasti nanti ada keluarga yang sakit atau meninggal dunia. Saya pernah bertemu, beberapa hari kemudian ada keluarga saya yang sakit. Jadi kitorang takut bertemu di laut." (KP)}

Kepercayaan ini berasal dari kejadian-kejadian yang dialami oleh tetua dahulu dimana ketika mereka pergi memancing dan tiba-tiba bertemu dengan hiu paus maka tidak lama kemudian salah seorang anggota keluarganya akan ada yang tertimpa sakit parah atau bahkan hingga meninggal dunia.

Ketakutan masyarakat terhadap hiu paus secara berangsurangsur mulai hilang terutama untuk generasi muda Kwatisore. Ketakutan terhadap hiu paus sudah mulai hilang semenjak banyaknya para wisatawan yang berdatangan untuk meneliti atau melihat hiu paus. Selain itu bagi generasi tua ketakutan mereka terhadap hiu paus saat ini terbatas hanya ketika mereka bertemu hiu paus saat sedang melaut sedangkan apabila bertemu hiu paus di bagan tidak akan membawa kedukaan bagi keluarga mereka. Berbeda dengan dahulu, dimana ketika melihat hiu paus masyarakat akan langsung berusaha kabur atau apabila hiu paus tersebut tiba-tiba muncul didekat perahu, maka masyarakat akan langsung menundukkan tubuh mereka ke dalam perahu. Hal ini sebenarnya cukup berdampak buruk bagi keberlangsungan keberadaan hiu paus karena dahulu masyarakat tidak pernah berani mendekati hiu paus namun sekarang ketika masyarakat mendapatkan permintaan atau pesanan terhadap sirip hiu paus, masyarakat menjadi tidak segan-segan untuk menangkapnya. Mitos hiu paus sebenarnya secara tidak langsung telah melindungi hiu paus dari eksploitasi. Namun semakin banyaknya wisatawan yang datang semakin mengubah persepsi warga Kwatisore terhadap hiu paus. Konservasi terhadap hiu paus akan tetap berjalan apabila masyarakat diberikan pengertian yang mendalam mengenai makna hiu paus bagi Perairan Kwatisore, dimana manfaat perlindungan akan memberikan nilai ekonomi yang lebih besar dibandingkan apabila masyarakat memburu hiu paus hanya karena pesanan beberapa orang saja. Penekanan terhadap manfaat ekonomi dijadikan alasan karena saat ini warga Kwatisore sangat mengedepankan peningkatan pendapatan mereka untuk mensejahterakan keluarga.

\section{Dampak Nelayan Bagan dan KJA}

Kehadiran nelayan bagan dan KJA memberikan dampak bagi kehidupan warga Kwatisore yaitu terjadi perubahan pada alat penangkapan ikan dan perahu yang digunakan. Dahulu warga Kwatisore pergi melaut untuk mencari ikan menggunakan jenis perahu dayung, dengan sistem one day fishing. Sedangkan alat tangkap yang digunakan adalah najagre apre semacam alat bunyi-bunyian yang digunakan oleh nelayan untuk menarik ikan datang kearah nelayan berada, tombak, dan DKPOP (2011) menjelaskan nelayan juga menggunakan pancing yang terbuat dari tali genemo yang diikat pada kayu kemudian menggunakan kail yang terbuat dari kawat yang dibengkokan dan diikat pada ujung dari tali genemo.

Seiring berjalannya waktu dan banyaknya interaksi yang dilakukan oleh warga Kwatisore dengan nelayan pendatang seperti bagan sedikit banyak merubah teknologi perikanan komunitas Kwatisore. Alat pengundang ikan najagre apre bisa dibilang sudah punah karena tidak pernah lagi digunakan oleh warga Kwatisore. Alat pancing yang terbuat dari tali genemo pun juga ditinggalkan diganti dengan alat pancing yang terbuat dari tali nilon, hanya tombak yang hingga saat ini masih digunakan oleh warga Kwatisore. Tombak tersebut digunakan pada saat menyelam (molo).

Selain alat tangkap, transportasi yang digunakan untuk melaut pun sudah berganti walaupun dayung hingga saat ini tetap menjadi andalan warga Kwatisore untuk one day fishing. Warga Kwatisore sudah banyak yang menggunakan perahu fiber untuk menangkap ikan. Perahu fiber didapatkan oleh warga secara gratis dengan syarat mereka bersedia menjadi anggota dari Keramba Jaring Apung (KJA) UD Pulau Mas.

\section{KESIMPULAN DAN SARAN}

\section{Kesimpulan}

Dari hasil penelitian didapat bahwa (1) Keberadaan zonasi tidak mengganggu aktivitas warga Kwatisore dalam mengakses sumber daya alam untuk tujuan pemanfaatan ekonomi, namun zonasi berpengaruh terhadap pengelolaan akses sumber daya karena terdapat BBTNTC yang ikut mengelola TNTC serta DKP yang pengelolaannya berfokus pada sumber daya perikanan; (3) keberadaan pariwisata selain memberikan tambahan pemasukan bagi warga kwatisore, namun juga menghilangkan mitos hiu paus sebagai hantu laut; (3) keberadaan bagan dan KJA sedikit banyak mempengaruhi pergantian alat tangkap warga Kwatisore dan transportasi yang digunakan untuk melaut seperti dahulu warga Kwatisore pergi melaut menggunakan perahu dayung, sedangkan saat ini nelayan lebih dominan menggunakan perahu fiber yang diberikan oleh KJA.

Jadi adanya penetapan zonasi, perkembangan pariwisata dan kehadiran nelayan bagan serta KJA tidak membuat warga Kwatisore menjadi termarginalkan, namun berdampak pada akses kontrol warga Kwatisore terhadap sumber daya Kwatisore. Terjadi dualitas kepemimpinan antara warga Kwatisore, BBTNTC dan DKP dalam pengelolaan sumber daya. Akibatnya wisatawan, pengusaha wisata, nelayan bagan, dan KJA merasa bingung dan dirugikan, namun mereka juga telah mengambil posisi keberpihakan. Posisi keberpihakan lebih dominan mengarah pada warga Kwatisore. Oleh karena itu warga Kwatisore masih memiliki posisi tawar (bargaining position) yang kuat dalam pengelolaan sumber daya alam menurut para aktor yang mengakses sumber daya Kwatisore.

Penelitian yang telah dilakukan membuktikan bahwa masyarakat adat masih memiliki posisi dalam pengelolaan 
sumber daya alam. Tindakan kolaborasi merupakan alternatif terbaik dalam pengelolaan sumber daya sehingga tidak hanya melindungi sumber daya melainkan juga dapat dimanfaatkan secara berkelanjutan dan terhindar dari konflik.

\section{DAFTAR PUSTAKA}

[BBTNTC] Balai Besar Taman Nasional Teluk Cenderawasih. 2012. Laporan Tahunan Balai Besar Taman Nasional Teluk Cenderawasih. BBTNTC: Manokwari

Denzin, Lincoln. 2009. Handbook of Qualitative Research. Dariyatno dkk, penerjemah. Pustaka Belajar: Yogyakarta.

[DKPOP] Dinas Kebudayaan Pemuda Olahraga dan Pariwisata. 2011. Profil Suku-Suku Asli Kabupaten Nabire Provinsi Papua. DKPOP: Papua.

Fatem S, Laar JV, Soyer JL, Manusawai J. 2011. Potrait of Community Mapping Stages Through Zoning Zystem on Managemen of Teluk Cenderawasih National Park, West Papua. Tiger Paper Regional Quarterly Bulletin on Wildife and National Parks Management. AprilJune 2011, Vol 38/2, pp. 13-19.

Humaeni A. 2012. Makna Kultural Mitos dalam Budaya Masyarakat Banten. Jurnal Antropologi Indonesia, Vol. 33/3, pp. 159-179.

Jaja JM. 2014. Myth in African Concept of Reality. Int.J.Educ. Admin.Pol.Stud, Vol. 6/2, pp. 9-14. DOI: 10.5897/ IJEAPS11.060.

Jahan Y. 2016. Intersection of Marginalization and Inequality: A Case Study of Muslim in India. J Pol Sci Pub Aff, Vol 4, pp. 187. DOI:10.4172/2332-0761.1000187.

Lynch OJ, Harwell EE. 2002. Whose Resources? Whose Common Good?.): Center for International Environment
Law (CIEL): Washington.

Mahmud A. 2014. Dinamika Tata Kelola Kawasan Konservasi Taman Nasional Bali Barat [Tesis]. Bogor (ID): Institut Pertanian Bogor.

Meinzen-Dick, Knox A. 2001. Collective Action, Property Right, and Devolution of Natural Resource Management: A Conceptual Framework. Di dalam Meinzen-Dick, Anna Knox, Monica Di Gregorio, editor. Collective Action, Property Right, and Devolution of Natural Resource Management: Exchange of Knowledge and Implication for Policy. Germany: German Foundation for International Development [DSE] and Food Agriculture Development Centre [ZEL].

Nahdian FB, Fadli A. 2014. Konservasi Berbasis Rakyat: Sebuah Pilihan Bagi Keberlanjutan Layanan Alam dan Kesejahteraan Rakyat [Internet]. [Tanggal akses 20 September 2014]. Diunduh dari: www.walhi.or.id.

Ostrom E, Schalager E. 1996. The Formation of Property Right. Di dalam: Hanna SS, Folke C \& Maler KG, editor. 1996. Rights to Nature: Ecological, Economic, Cultural, and Political Principles of Institutions for the Environment. Island Pr: Washington DC.

Peluso NL, Ribot JC. 2003. A Theory Of Access. Rural Sociology, Vol 68/2, pp. 153-181.

Tampubolon FL, Satria A. 2013. Hubungan antara Nelayan Jepara dan Karimunjawa dalam Memanfaatkan Sumberaya Perikanan Di Taman Nasional Karimunjawa. Jurnal Sodality, Vol 01/3, pp. 200-205.

Winara A, Mukhtar AS. 2011. Potensi Kolaborasi dalam Pengelolaan Taman Nasional Teluk Cendrawasih Di Papua. Jurnal Penelitian Hutan dan Konservasi Alam, Vol 8/3, pp. 217-226 